\title{
¿Dónde está el sujeto?: problemas de representación de los pueblos originarios en el cine
}

Alejandra F. Rodríguez *

\begin{abstract}
Resumen: En la representación del pasado, sea como drama o como documento, los filmes recurren al archivo, se valen de alguna fuente pictórica, documental o de restos materiales, pues encuentran allí un poder de legitimación intrínseco, más allá del uso que luego pueda hacerse de estas fuentes. El trabajo propone el análisis de dos documentales recientes que abordan la problemática de la llamada Conquista del Desierto: El país del Diablo de Andrés Di Tella (2008) y Tierra Adentro de Ulises de la Orden (2011). Se plantean algunas hipótesis acerca de cómo construye el verosímil el cine de tema histórico, qué lugar tiene el archivo en esa construcción y qué tipo de uso se hace de las fuentes documentales, iconográficas, y, principalmente, de los testimonios orales en dichas representaciones. Se intenta dar cuenta de algunas relaciones texto-contexto, además de indagar sobre las nociones acerca de la historia que ponen a rodar ambos filmes.
\end{abstract}

Palabras clave: cine - historia argentina - pueblos originarios - documentales - análisis cultural.

[Resúmenes en inglés y portugués en la página 43]

${ }^{(*)}$ Historiadora. Magíster en Sociología de la Cultura y Análisis Cultural. Profesora regular de Cine e Historia y de Historia Argentina en la Universidad Nacional de Quilmes. Se desempeña como investigadora del Centro Historia Cultura y Memoria de esa Universidad, donde dirige el proyecto I+D “Cine, estética y política”.

Integró la comisión directiva de la Asociación Argentina de Estudios de Cine y Audiovisual AsAECA y fue Presidenta del V Congreso Internacional de Estudios de Cine y Audiovisual. Ha recibido subsidios FONCyT y CONICET. Integra el comité científico de AsAECA. Desde 2012 dirige la Lic. en Ciencias Sociales y Humanidades de la Universidad Nacional de Quilmes.

\section{Introducción}

El País del Diablo es una de las 13 películas de "Fronteras argentinas", una serie producida por la Secretaría de Cultura de la Nación y el canal Encuentro, que explora en límites concretos y metafóricos de las fronteras en nuestro país y en nuestra historia. En esa convocatoria realizaron filmes, entre otros directores, Cristian Pauls, Albertina Carri, Verónica 
Chen, Diego Lerman, Ignacio Masllorens, Pablo Trapero y Sergio Wolf. La que estamos analizando estuvo a cargo de Andres Di Tella, director de Montoneros, una historia (1998); La televisión y yo (2003); 327 cuadernos (2015); entre otros filmes.

La película se pregunta por un personaje: Estanislao Zeballos (1854-1923), quien fue estanciero, escritor, abogado, periodista, diputado, y quien es considerado como "un intelectual orgánico de la Conquista del Desierto", por su defensa fervorosa de la avanzada sobre las tierras indias. Sin embargo, el filme no indaga demasiado estas dimensiones sino más bien el hecho de que fue un individuo atravesado por una experiencia compleja: la proximidad del otro. A través de los escritos que dejó, la película irá adentrándose en lo que fue la frontera con el indio hacia fines de 1870.

Son las fuentes las que guían esta suerte de road movie. El libro de Zeballos Viaje al país de los araucanos será la brújula; los mapas del walmapu se convertirán en la hoja de viaje, construyéndose en instrumento y también en el tesoro a descubrir y mostrar. En este sentido, la primera parada importante en el viaje es la laguna Quiñé-Malal, donde Zeballos encontró el archivo del gobierno de Salinas Grandes; es decir, donde se topó con los papeles que Calfulcurá había intentado ocultar en su fuga. Gracias a la puesta en serie, el protagonista pasa del lugar de los hechos al archivo. La cámara lo encuentra abriendo el bibliorato en el que se encuentran las fuentes aludidas. Di Tella saca de sus folios, toca, lee, manipula esas fuentes descuidadamente como si se descubriera ese tesoro por primera vez. Con este recurso se establece la primera asociación entre el director y Estanislao Zeballos. Más adelante, el vínculo se completa cuando Di Tella revisa fotos, retratos del teórico de la conquista, mientras su voz en off declara: "Zeballos: Una especie de documentalista como yo". Se recorre lo que fueran las inmediaciones de la laguna para encontrar, en esa tierra construida por la cámara como desolada, algo que ayude a entender lo que -parafraseando a Terán- llamaremos "el momento en que se corta el hilo de los días". Las palabras desgarradas del cacique Namuncurá dan cuenta de la traición del acuerdo de paz firmado en Caruhé, así como del cambio del proceso histórico:

Por lo que estoy entretenido suponiendo que deberá ser alguna traición, por lo que estando en este trabajo me vino a pisar el campo, en cautivar familias y pasar por las armas a mis indios. // y espero que Dios me ha de ayudar en el triunfo; que si Dios no permite que salga victorioso, entonces podremos morir todos nosotros, que después de muertos no sentiremos nada (carta firmada por el Cacique Manuel Namuncurá, en Salinas Grandes, el 5 de febrero de 1878).

Sin duda, la misiva condensa el cambio de la coyuntura política y económica. A partir de la década del 70, no solo se prioriza la incorporación de espacio pampeano patagónico y sus recursos, sino que, en la medida en la que el estado construye su territorio, plantea la disolución del orden tribal y la utilización de los indígenas en dicho orden. Es allí cuando se impone un discurso que homogeniza y salvajiza a los pueblos originarios. La idea de "misión civilizatoria" que enuncia Zeballos se va constituyendo en una visión denigrada del otro. El indígena representará, desde entonces, un otro externo a la nación, pero interno a un territorio que el Estado reclama como nacional. Este proceso será acompañado de una mitología en la cual se construye el territorio como desierto y sus habitantes como salvajes. 
En esta "excursión" de Di Tella hacia lo que fue la "frontera con el indio", las fuentes adquieren valor dramático y narrativo, pues son el motivo que hace rodar la historia. La película se desliza entre la lectura de esas fuentes, las reflexiones en voz alta del director, y esa superficie: esa geografía a la que considera espacio de memoria. Mediante la voz en off de su protagonista, se da cuenta de algunos elementos de la narrativa tradicional, a la vez que se indaga en las huellas, de lo que alguna vez fue la zanja de Alsina. La cámara busca y encuentra las marcas visibles de aquel proyecto inconcluso que, además, en algunos atardeceres es posible advertir desde el cielo. De esta manera, expone los trazos de los paisajes vistos o imaginados por Estanislao Zeballos en su aventura al corazón de lo que fue el imperio de Namuncurá.

\section{Identidad y contexto}

Una de las líneas que la película despliega es en torno a la pregunta sobre la identidad. Dos secuencias (que pertenecen a momentos distintos), pero que componen un mismo dialogo entre Nazareno y su padre, resultan significativas; la primera, nocturna, alumbrada por el fogón de la casa; y la segunda en el patio, al amanecer. En ellas se evidencian diversos relatos que tensionan la propia familia del cacique Nazareno; las opiniones del padre sobre los indios son negativas, los califica de ladinos y traidores, pone distancia con ese pasado y esa gente: “... por buenos no los habrán echado...”. Su hijo introduce la pregunta: “¿Por qué pensás que actuarían así?"

En la escena siguiente, el padre reflexiona sobre la constitución de la identidad a partir de los espacios a los que no pudo acceder por su color de piel (debido a la sangre india de su madre):

Los indios no querían ser indios... ahora los que quieren se identifican... Eso fue cuando él empezó (señala a Nazareno) a rescatar la lengua, las cosas y después de Nación se apoyó un poco con una ley y después el gobernó dijo y si... vamos a tirarles unos mangos a éstos pero para que rescaten la cultura... Ahí recién se empezó a dar cuenta... ¿Qué calienta ser indio? Soy y listo.

Pero ¿por qué? ...los discriminaban mucho a los indios...entonces ¿quien quería ser?

Por ejemplo, acá nomás en Viedma, había un Club Social que lo fundaron los italianos, franceses; ahí no podía entrar un indio, ni quien tuviera una raza muy cerca... por ejemplo aunque sea hijo, de alguno del club, como el caso de mi padre... Yo entré una sola vez al club...o sea... yo sabía que tenía sangre india...

Concluye, dejando sobrevolar la pregunta por el presente: “¿Quién quiere ser indígena hoy? ¿Qué significa en este presente reconocerse inscripto en ese pasado y en ese pueblo?". El contexto aparece a contraluz, tensionando el testimonio, y da cuenta tanto de la realidad vivida por el sujeto como de la existencia de un cambio del clima de ideas, de un nuevo contexto que implicó el reconocimiento y cierta ayuda económica del Estado hasta entonces inexistente. 
Otra de las voces que el filme recoge es la de Daniel Cabral, a quien se presenta como uno de los últimos hablantes nativos de ranquel. El maestro da testimonio de las humillaciones y castigos sufridos en la infancia por el hecho de hablar esa lengua; así las marcas en el cuerpo hablan de otros campos de batallas donde el tropos civilización o barbarie también dejó huella.

Por su parte, los apuntes de Zeballos, sus dibujos y fotografías, dan lugar a la reflexión sobre la cuestión científica, invitan pensar en torno a las fuentes y al Positivismo. Vanni Blengino (2005) plantea que en ese contexto histórico la oposición civilización-barbarie fue acompañada, y en ocasiones sustituida, por la oposición historia-prehistoria; y que es el tiempo el que sustituye al espacio como horizonte de conflicto. De este modo, todo lo que concierne al indio y a la naturaleza que lo circunda remite a un anacronismo. Se inventan nuevos nombres, se clasifica fauna y flora, se cuentan kilómetros, se registran altitudes, se enumeran muertos, y se recolectan sus huesos para el museo. Se construye, así, una nueva poética militar positivista. Vemos restos de esta cuando la película nos ubica en el subsuelo del Museo de Ciencias Naturales de La Plata. Allí, cientos de cráneos de indios ordenados y numerados dan cuenta de esa lógica.

Claudia Torre (2009, p. 256) en su breve reseña del filme señala:

De acuerdo a las explicaciones del empleado del museo no es posible saber quién es cada uno, sino apenas quiénes son todos. Porque no se trataba de matar gente para la experimentación científica, sino de exhumar los cementerios para el coleccionismo público y privado. Lo que nos recuerda que no todos los errores son semejantes y que la reflexión sobre el mal no debe banalizarse con asociaciones rápidas.

En el filme, esos huesos anónimos de indios vencidos, recolectados para indagar las diferencias evolutivas de la especie, parecen hacer contrapunto con los primeros planos de las personas, a quienes el fotógrafo José Depetris intenta restituir identidad y genealogía. Sin embargo, cabe señalar que la fotografía también fue parte de la lógica positivista, de aquello que se necesitaba preservar antes de que se extinguiera: la indumentaria de los indios, su temperamento, etc. Se trataba de sujetos devenidos en objetos de estudio. Estanislao Zeballos conformaba la Sociedad Científica Argentina que organizó las primeras exposiciones fotográficas en los años 70. En esta lógica, era necesario dejar registro de la evidencia física de la diferencia, de eso otro, que estaba al margen de esa sociedad pujante de orden y de progreso.

\section{Tierra adentro}

Tierra adentro toma mucho de los temas planeados por Di Tella años antes, para abordar las llamadas Conquista del Desierto y Pacificación de la Araucanía en Chile. El filme de De la Orden, pone en escena cinco líneas narrativas: un programa de radio de Bariloche, donde se entrevista al historiador Walter Delrio; el viaje de Marcos, descendiente del general Racedo -comandante de la campaña al desierto de Roca-, junto a Anahí, descendiente ma- 
puche, los que se dirigen hacia las tierras "conquistadas" por su ancestro; la de un comunicador chileno, Alfredo Seguel, que intenta recuperar la memoria histórica de los abuelos a ambos lados de la Cordillera; la de Pablo, un adolescente de Bariloche que se acerca a las tradiciones mapuches a la vez que problematiza su propia identidad; $y$, por último, la de un historiador de Buenos Aires, Mariano Nagy, que expone, a través de sus clases, el contexto general en el que se desarrolló la conquista y, además, indaga en diversos archivos guiado por su hipótesis: "estamos trabajando para demostrar que se trató de un genocidio".

El filme toma ideas y preocupaciones de la investigación que realizara el historiador Walter Delrio, publicada en 2005 con el nombre de Memorias de expropiación. Sometimiento e incorporación indígena en la Patagonia 1872-1943. En ella se analiza el fondo documental clásico, junto con los dichos que formarían parte de la memoria de los pueblos originarios. Construye, así, un análisis y una periodización de la historia que incluye también esas fuentes orales.

El enunciado fílmico descansa, a su vez, en la premisa de que existe un olvido o una infamia respecto de la historia con los pueblos originarios, por lo que insiste en la exhibición de numerosas fuentes, documentos, objetos, imágenes y testimonios que pondrían en el centro de la escena un real traumático, que parece no haber sido inscripto en la trama histórica nacional.

El periodista irá tras las palabras que puedan echar luz sobre ese trauma en un viaje por las tierras que conformaron el Wallmapu $u^{1}$, donde recoge testimonios de diversas personas mayores. Dos ancianas relatan los dichos de sus abuelos sobre el momento en el que los extranjeros se apropiaron de las tierras que les pertenecían, y de las múltiples humillaciones sufridas. Un familiar del cacique Nahuelquir, de 86 años, rememora escenas de su vida de pequeño cuando vivía en una choza de barro, junto a otras historias "contadas por su gente"; y, entre ellas, destaca el ataque del "malón", concepto que usa para referirse al ataque del ejército:

Seguel pregunta: $Y$ acá, la campaña del Desierto, ¿ fue muy dura?

Nahuel responde: Y sí, me contaba mi gente que hubo un malón tremendo, doloroso. Dicen que íbamos partiendo para Chile. Íbamos como 150 familias y descansamos en un vallín, cuando, en una de esas, se abalanzan los militares. Contaban ellos que a las mujeres les cortaban el seno vivo, a los niños los levantaban con la lanza delante de sus madres. También me contaron de los hombres mayores, que los ponían en una madera y los ataban, y les cortaban los brazos, en carne viva. ¿Sabe lo que es? Morir así... un dolor tremendo. Y así mataban a la gente en aquel tiempo... es muy doloroso.

Llegado este punto, es difícil señalar en calidad de qué se realizan las entrevistas. No se trata de testigos, $y$ tampoco es posible considerarlos sobrevivientes por la distancia temporal de los hechos que relatan ocurridos hace más de un siglo. Se podría pensar que constituyen relatos sobre la historia transmitidos de forma oral; experiencias de un tiempo no vivido. Cynthia Tompkins (2017) los enmarca en una posmemoria a la que entiende, según Hirsch, como la reacción de la segunda generación ante experiencias traumáticas que los precedieron, pero que al serles transmitidas les hicieron un impacto tan profundo que 
aparecen como si fueran sus propias memorias (Hirsch, 103-2008). En otras palabras, se trataría de la posmemoria una "estructura inter - y trans-generacional de transmisión de experiencias y conocimiento traumático"2 (2017, p. 497).

El tratamiento que el filme ofrece de las entrevistas a miembros de las comunidades indígenas (que son consideradas testimonios) es cuidadoso y diferenciado. Gracias al montaje, esa memoria aparece como espacio de la disidencia histórica y, también, como contrafigura de la historia institucional. Se impone, entonces, la interrogante sobre las memorias de los ancestros, conjuradas como rememoración y repetición, y sobre algunos significados compartidos y cristalizados que estas expresan. Por otro lado, esos relatos actualizan escenas de humillación y exclusión recientes. La historia, entonces, se representa en este filme siempre igual a sí misma. También como una herida abierta.

\section{Desde las paredes y las vitrinas}

Si el documental pone en cuestión el discurso hegemónico a través de la exposición de una memoria oral resistente que se considera aún audible, también recurre a los documentos y a la iconografía. Nunca se aleja de las fuentes para dar su versión; la preocupación por el archivo se expande en varios sentidos, y uno de ellos se propone como desmitificador. La voz en off del historiador interroga sobre cuáles son las imágenes que se tienen para pensar esta historia, mientras la cámara recorre las salas del Museo Nacional de Bellas Artes, para detenerse frente a La vuelta del Malón (de Ángel Della Valle, 1892).

Se reencuadran algunos de sus detalles, y un paneo descendente se desliza desde la cruz hacia el indio semidesnudo que la empuña; se hace foco en la cautiva blanca que se halla en manos de los raptores, y luego el detalle de la valija robada se advierte en el centro de la escena; de este modo, logra condensar una idea de lo que esta imagen dice: los indios son salvajes, ladrones de riquezas y de cuerpos.

El montaje se detiene luego en un rostro, al que la voz en off señala como responsable de la Conquista: se trata de Roca. La puesta en serie ha trasladado al espectador al Museo Histórico Nacional que aloja el enorme óleo llamado La ocupación militar del Río Negro (J. M. Blanes, 1889). Desde allí, la voz del historiador denuncia que aquella reunión (también plasmada en el billete de \$100) de Roca con sus generales nunca existió. Los militares, cuyos rostros acaban de mostrarse, no se reunieron en campaña; menos aún los científicos y agrimensores que iban a encargarse de mensurar la tierra conquistada. La imagen más famosa de esta campaña nunca existió en realidad, es falsa (dice Nagy), y queda en suspenso la invitación a la reflexión acerca de la legitimidad y la verosimilitud de las imágenes con las que se ha "imaginado" -y, por tanto, construido- nuestra historia.

De este modo, el óleo abandona su lugar de mito de la patria para convertirse, más que en un objeto contextualizable, en una prueba de la interpelación del pasado que sostiene el filme.

En otra escena, la cámara entra a la catedral de Bariloche junto al adolescente, y vemos, desde su punto de vista, los vitrales de este recinto. El contrapicado desde el que observa con ávidos ojos negros aquello que narran las imágenes, en absoluto silencio y desde abajo, es incómodo. Las imágenes no solo endiosan a Roca, sino que reproducen los tópicos 
de civilización-barbarie. Los indios semidesnudos aparecen como asesinos de religiosos. Es posible vincular este enunciado con los conceptos que Walter (1970) sostuvo desde el Círculo Militar en esos años, y que significaron unir la Conquista española, la evangelización, la gesta de la independencia y la guerra contra el indio en un mismo enunciado civilizador. La catedral, construida en 1942 (450 años después de la Conquista española), da cuenta de que esas nociones siguieron siendo productivas. Así, la politicidad de la imagen y su capacidad performática se convierten en tópico del filme.

Otro modo de acercamiento al archivo que propone la película acontece cuando se pasa de la idea a la prueba. En varios momentos se recurre al archivo como espacio donde algo de lo verdadero se revela; el investigador (lupa y/o cámara en mano) sigue la pista y da con las evidencias. Recorre los anaqueles de la Biblioteca Tornquist del Banco Central para ojear el expediente del empréstito de tierras públicas de 1778, mediante el cual las empresas privadas, los grandes nombres del momento, financiaron la llamada Conquista del Desierto. El primer plano de los bonos de financiamiento antecede a la exposición de los resultados económicos de la empresa de conquista. Se exhibe, a continuación, el mapa del catastro inglés de tierras de 1882, que da cuenta de las nuevas propiedades en Buenos Aires, Santa Fe, Córdoba, San Luis y La Pampa, mientras se escuchan los nombres de Quintana, Martínez de Hoz, Roca, Runciman, Alvear, Unzué, Luro, Anchorena y muchos más entre los que se listan varias compañías inglesas. "En tres décadas se repartieron casi 42 millones de hectáreas entre menos de 2000 terratenientes", dice la voz en off del historiador. Las pruebas están allí, el pasado y el archivo están disponibles para nuevas lecturas.

El filme problematiza, también, los objetos; los restos materiales del pasado que, en la mayoría de los casos, se atesoran y se coleccionan en museos pequeños o familiares: Museo Carhué, Museo Raone, Museo Guaminí, Museo Rural Bernasconi. La narración se detiene, también, en la exquisita Fundación Proa de Buenos Aires. Allí luce la belleza de los objetos de platería y de textiles Pampas en maniquíes sin rostro: en todos ellos, un vacío, una omisión. Son objetos ilegibles, ciegos al estar omitido su contexto y los sujetos sociales que los han producido, según plantea el filme.

En una de las visitas a los propietarios de la zona cercana a Carhué, y ante la observación de aquella casa que es como un museo, debido a que todos sus muros y rincones están poblados de objetos indígenas, la mujer responde: "Sí, refleja nuestra propia historia...", reflexiona, y luego agrega: "la historia con el nativo". Queda flotando la idea de que no fue una historia con el otro, sino una historia sobre el otro, de una victoria y de un saqueo. Se impone la sospecha de que son objetos apropiados; y el cuadro siguiente, y la voz en off de Nagy, refuerzan la idea.

De esta manera, los espacios museísticos se plantean en el filme como testimonios activos de la dominación. Da cuenta de eso, también, el punto de vista desde el que la cámara toma al museo de Ciencias Naturales de La Plata; un contrapicado que muestra el edificio con un recorte similar al usado en el género de terror. La mirada desde el llano hacia el gran edificio y la voz en off del periodista Alfredo Seguel, que advierte de la existencia de miles de restos humanos en los sótanos, sumado a la sobreimpresión de las fotos del museo tal como era en el siglo XX, cuando exhibían en anaqueles los cuerpos de los vencidos, construyen la idea del museo como eslabón final de la cadena de la infamia. Desde esta perspectiva, se lo considera un monumento al holocausto de los pueblos originarios. 


\section{Del fondo de los archivos a la superficie de la tierra}

La tierra aparece problematizada en la película de Ulises de la Orden. Se plantea como teatro de la memoria y también como superficie donde se inscribió el terror. Ese es el sentido construido alrededor de la visita a la isla Martín García ${ }^{3}$, no solo porque pone en escena la existencia de prisioneros de guerra, que eran traficados en nuestro país 70 años después de que fuera abolida la esclavitud, sino también porque fue destino final de muchos de los vencidos.

En ese marco, el filme intenta reconstruir la historia del Cacique Pincén, cuyo rastro llega hasta la isla Martín García. Se entrevista a Lorenzo Pincén, descendiente de ese Cacique que fue uno de los últimos que resistió al Estado argentino hasta 1878.

Lorenzo lo señala como el dueño de todas las tierras y el primer desaparecido:

-Hicieron un desastre los remington esa mañana, mataron a gente que estaba durmiendo, a mujeres, a niños, a ancianos. Fue terrible lo que han hecho. (...). -Una vez detenido Pincén, ¿dónde lo llevan?

-Se reconoce que el hombre estuvo preso en la isla Martín García, que era el campo de concentración. Pincén tiene orden de entrada, pero no tiene orden de salida, o sea que él desapareció allá. Se lo llevaron ellos mismos, no sabemos dónde, si le dieron sepultura, lo arrojaron al mar, al río. No sé lo que le habrán hecho...Estamos buscándolo; para nosotros es el primer desaparecido del estado argentino. Como República Argentina nosotros tenemos el primer desaparecido, que es el cacique Pincén, el dueño de todas las tierras. Nosotros vamos a ejercer ese derecho y reconstruir nuevamente nuestra nación: el Wallmapu, que vuelva a sus manos, a sus tierras... porque tenemos que dejarle algo a nuestros hijos y dejarle algo a las futuras generaciones. Creo que lo vamos a lograr.

Esta secuencia pone en escena el contexto de lectura de esta historia, que no es solo el que habilita la reforma constitucional de 1994, que restituye visualidad a los pueblos originarios y plantea la existencia de la propiedad comunal indígena, sino también de la segunda oleada de juicios de lesa humanidad, en los que se profundiza el conocimiento sobre la apropiación de personas, la complicidad civil, y los delitos económicos de la última dictadura. Los testimonios elegidos en este filme tejen permanentes referencias entre la historia del siglo XIX y la de la última dictadura. Esta escena, además, condensa la existencia de un actor social activo en la búsqueda de una restitución material de las tierras.

\section{Memoria e historia en ambos filmes}

En Tierra Adentro son permanentes la tensión y el movimiento entre documentar la historia y hacer lugar a la memoria; entre el relativismo y la multiperspectividad; entre las explicaciones presentes y las pasadas de la historiografía.

Algunos de los elementos de las explicaciones más tradicionales están esbozados en la entrevista que el descendiente de Racedo mantiene con Juan Raone, uno de los propietarios 
de la zona, quien sostiene, mientras la cámara realiza un paneo sobre sus credenciales, que el territorio era un desierto en manos del indio:

(...) Roca, con gente como Racedo, ponen la espada y la gente para limpiar, todo eso, y se limpia. Y se acaba todo eso (...). Yo no tendría todo esto y usted no estaría sentado acá si no hubiera habido gente como Racedo. Así se hizo el país, porque empezamos a tener agricultores, agricultores, ¿argentinos?... Eran europeos... Esa es la gloria de esta gente.

Las credenciales de Raone dan cuenta de que, en 1991, aun careciendo de formación específica, fue nominado como miembro de la Academia Nacional de la Historia, legitimando su perspectiva historiográfica (la que expuso en los tres tomos sobre los fortines ${ }^{4}$ ) en sintonía con aquellas postuladas por una historiografía tradicional y una geografía clásica, que consolidaron, durante esos años, ideas sobre la frontera como un territorio casi vacío, ocupado solo por bandas nómades o seminómades que subsistían gracias al pillaje y que, por lo tanto, constituían obstáculos a remover para dar inicio a la Historia Argentina (moderna, occidental y capitalista). La idea de que para que la Historia argentina empiece, la otra (la indígena) debe ser ocluida, está presente en varios relatos expuestos en el filme.

Sin embargo, la película marca un contrapunto con la puesta en serie, pues, a continuación del relato de Raone, que alude a la limpieza necesaria, monta el testimonio de una mujer mapuche que da cuenta de lo escuchado de boca de su abuela respecto de la fundación de los parques nacionales. En su relato no hay épica, no hay héroes, no hay nación; solo violencia y sobrevivientes de las políticas del estado. La película, entonces, articula su enunciado en la tensión entre aquello que es considerado testimonio, fruto de una memoria oral ancestral, y aquello otro sostenido por los testigos más blancos y más ricos, que estaría cercano a la interpretación tradicional o historiográficamente dominante. Dicho contraste replica la lógica binaria de voces de víctimas y beneficiarios, mientras reitera la división tradicional entre oralidad y escritura, entre cultura dominante y cultura subalterna.

Por su parte, la cuestión de los testimonios reviste una capa de mayor complejidad en estas representaciones, donde es lábil la frontera entre actuación y experiencia; característica que esta película comparte con otras contemporáneas. En ambos filmes los personajes hacen de sí mismos: el director de cine, el maestro, el cacique, el periodista, el historiador, el descendiente de Racedo, la descendiente mapuche, el adolescente de Bariloche. Se presenta, así, un doblez persona/personaje, pues se trata de personas que no dejan de ser personajes que condensan o simbolizan actores sociales, y que se mueven dentro de una narración guionada. Párrafo aparte merece Amadori, propietario de la zona, cuyo testimonio se actualiza en los dos filmes estudiados.

En El país del diablo, ante la siguiente pregunta, Amadori responde:

-Usted que conoce la historia: ¿qué le parece la reivindicación de los indios? -Estoy totalmente en contra, era imposible ponerse de acuerdo con los tipos esos, un día decían una cosa, otro decían otra y cuando vieron que Roca no iba a jorobar y les iba a dar, se vieron que estaban perdidos y empezaron a irse. 
¿Y para donde se iban? para el lado que habían venido... es como cuando uno corre un animal salvaje, ¿para qué lado va? Para el lado que conoce mejor.

Aquí se exponen algunos tópicos que salvajizan y animalizan a los pueblos originarios. En la siguiente entrevista, aparecen nuevos elementos:

Yo lo veo como que la campaña al desierto era una cosa necesaria, porque era un tema de soberanía con Chile y el tema indio tenía en jaque a todos los que estaban intentando poblar, era un tema preocupante para los que gobernaban, por los robos; otra cosa que no se tiene en cuenta, las cautivas, el secuestro extorsivo era un medio de vida de ellos.

Yo no juzgo ni a unos ni a otros, porque la civilización tenía que llegar. Es muy fácil mirarlo de ahora, pero hay que estar en el tiempo, en ese momento... no ha sido fácil.

Como sostiene Ana Amado (2011), la verdad en el cine social está asociada al testimonio, y la dramaturgia se construye a través de las palabras y de los cuerpos. Estos, como figuración ordenada bajo las leyes de un verosímil diferente del de la ficción, corresponden a personajes que se representan a sí mismos. Se trata de un conjunto de voces con conciencia de su papel de personajes en la escena. En este sentido, la puesta en escena que se logra en Tierra adentro supera a la del mismo testigo, obtenida por Di Tella, debido al escenario en que es pronunciada: ya no en una confitería del pueblo, sino en la tierra donde sucedieron los hechos. Allí los descendientes del europeo, del general conquistador del desierto, y la mujer mapuche despliegan un nuevo juego.

Siguiendo con la puesta en escena, es interesante observar también la construcción que el filme realiza de Mariano Nagy, pues la misma resalta su inscripción institucional, mediante la mostración de la placa en la entrada de la Facultad de Filosofía y Letras de la UBA y en la de la puerta de la oficina del Instituto de Investigaciones en que se desempeña. Sin embargo, la narración lo construye, más que como un académico, como un intelectual sartreano, activo portavoz de una conciencia humanista; su ética parece estar definida en términos de una misión: demostrar que hubo un genocidio. En esta definición de la persona/personaje prevalece el sentido moral: el historiador va a los archivos, no para escuchar lo que tienen que decir, sino para encontrar pruebas que sacudan la conciencia social. Amado sostiene, además, que en los filmes de este género se multiplican hoy las voces de testigos como modo de enfrentar la crisis contemporánea de verdad, las dudas sobre las evidencias de la historia, las grietas profundas en las instituciones (2011). El despliegue de historias, de testigos, y la búsqueda permanente de pruebas dan cuenta de ello.

En este sentido, es posible inscribir el abordaje que propone Tierra adentro dentro del fenómeno de globalización de los discursos de la memoria traumática (Huyssen, 2003), pues propone la categoría de genocidio como clave para entender los sucesos de la Patagonia. Esta remite al exterminio sistemático y deliberado de un grupo social por motivos raciales, políticos o religiosos. Estas ideas fuertes en el filme provocan también algunas tensiones en la enunciación. 
Como se mencionó, la escena que abre Tierra adentro tiene al historiador Walter Delrio en la radio planteando la inconveniencia de pensar el momento de la campaña contra el indio como bisagra de la historia, porque esto implica la aceptación de que allí comienza la modernidad y la racionalidad occidental frente a lo salvaje e irracional de la historia anterior; y esta idea reproduce una visión hegemónica que es necesario cuestionar. Sin embargo, este objetivo no puede ser cumplido por una película que tiene al genocidio como premisa orientadora de cuatro de las cinco historias (solo la del adolescente escapa al tema), y que se centra en esa bisagra, en develar el momento en que convierte en víctimas a esos actores sociales. La película no puede dar cuenta de esa vida anterior al hecho traumático que refiere. Ese es el borde de los archivos y de los interrogantes puestos en juego en la película de Ulises de la Orden.

La frontera antes de 1876, la frontera sur, como espacio ambiguo y de intercambio, queda obturada en la representación. Se alude brevemente a esta como punto de partida en los primeros mapas animados que se despliegan, o cuando Marcos y Anahí pisan la tierra de Carhué preguntando por Calfucurá, pero se trata solo de una alusión. Si bien el filme tiene varios pliegues, el sentido general de la enunciación construido alrededor de la búsqueda de la verdad, a partir de la hipótesis del holocausto indígena, desdibuja el conocimiento de esa sociedad previa. Si bien El país del Diablo no enuncia esa premisa, tampoco despliega capacidad de agencia de los pueblos originarios en la historia, debido a la estructura misma del filme, que inicia con el desembarco de Zeballos una vez vencidos los ranqueles, no lo habilita.

\section{Algunas tramas}

Como se señaló El país del Diablo busca explorar la mirada de ese individuo atravesado por la experiencia de la frontera, y es a partir de ese móvil que, encadenando fuentes y testimonios, compone una reflexión personal sobre el pasado y un cuadro donde se actualizan vivencias de quienes se identifican con uno u otro sector social que ha disputado en la historia. Por lo tanto, las fuentes escritas y visuales no revisten, en este filme, un status de prueba, sino principalmente una función dramática y una función ilustrativa. Puede puntualizarse, en este sentido, el montaje de escenas tomadas de El ultimo malón (1917) que refieren a la Santa Fe de principios del siglo XX, o a las secuencias del padre Agostini sobre Patagonia para rememorar las dudas de Zeballos en sus últimos días de vida.

En Tierra Adentro, en cambio, el despliegue de fuentes orales, escritas y visuales, está al servicio de establecer una "verdad" sobre el pasado. Como se señaló, las entrevistas se presentan como si fueran testigos de la historia, aún cuando ha trascurrido siglo y medio desde los hechos referidos. Estos relatos se funden con otros que remiten a experiencias más cercanas en el tiempo, como la fundación de Parques Nacionales (a partir de la década del 30) y otras experiencias de mediados del siglo XX. Todos los relatos son expuestos como parte de una memoria colectiva que da cuenta de un lugar de subalternidad y sometimiento que se reitera y afirma a lo largo de toda la historia nacional.

Ambas películas establecen, a partir de los testimonios, a quiénes podríamos denominar víctimas de la violencia estatal; un campo de voces divergentes, que hacen contrapunto 
con los dichos de otras personas ajenas a los pueblos originarios. Esos testigos/especialistas, como lo son: Amadori (cuyo testimonio aparece en ambos filmes) o Raone (en Tierra adentro) plantean ya no experiencias en primera persona, sino interpretaciones cercanas a las que fueron historiográficamente dominantes en gran parte del silgo XX. En este último caso, el montaje se encarga de reforzar la dicotomía, planteando la memoria como contracara de la historia institucional.

Cartas y retratos constituyen los documentos históricos que cargan mayor emotividad en ambas representaciones; las cartas, aquello que Bellour (2009) llama "el espacio elíptico de la pérdida", parecen dar cuenta de la primera persona, de la subjetividad y la humanidad de ese otro; ejemplo de ello es la lectura en la voz de Seguel de las cartas de Namuncurá, que hace Di Tella, o la que el indio cautivo le escribe a su mujer y que nunca llegó a destino, porque permaneció junto a muchas otras en el archivo de la Armada argentina.

Por su parte, ambos filmes incluyen, entre sus fuentes, fotos grupales de los pueblos originarios. Sin embargo, en los epílogos, son los retratos los que habitan y conmueven el plano, acompañados de una banda sonora que realza la sensación de pérdida. Aquellas fotos tomadas de frente y de perfil miran desde el fondo del tiempo. Marta Penhos sostiene, refiriéndose a las fotografías, que resultan una condensación extrema de la narración que, en vez de estar desplegada en una escena, se concentra en el rostro que cuenta toda una historia personal pero también genérica. Todo retrato es, a la vez, la imagen de una individualidad y de una tipología (Penhos, 2005). Más allá de la lógica -romántica o positivista- en la que se inscriben estas tomas, la fotografía, como dice Barthes (1992), trae también el spectrum de ese referente; $y$, cuando son montadas en el flujo cinematográfico, convocan una intensidad extraña al cine y son fantasmas del pasado convocados a llenar un vacío del que son también señal.

Como se señaló, El País del Diablo desembarca en la frontera guiado por Zeballos. Sin embargo, hacia el final del recorrido, es Nazareno, el cacique, quien lo guía hacia una tierra donde amenece -junto a otros descendientes de los pueblos originarios-, para celebrar el año nuevo ranquelino. Este final es similar en ambos filmes. De este modo, la celebración y la ritualidad funcionan como representación de la posibilidad de la trasmisión; como un aspecto central de la reescinificación (Andrea Franca, 2013) que posibilita tender puentes y también poner en tensión las imágenes del presente y del pasado.

En mismo sentido, el tema de la identidad, se aborda en ambos filmes, como algo incompleto y dinámico: las escenas mencionadas del cacique Nazareno y su padre, en El país del diablo; o el recorrido del adolescente Pablo, entre la escuela, la iglesia, y la ruca en Tierra Adentro, hablan de esa construcción compleja.

En ambos films, se expresa un contexto socio-histórico que fue plasmado en la reforma constitucional de 1994, en la que se establecieron los derechos de las poblaciones indígenas; la garantía y el respeto a la identidad, a la educación bilingüe, y a la posesión y propiedad comunitaria de las tierras que tradicionalmente ocupaban -entre otros derechos- (Carrasco, 2000). Por su parte, es indudable que el contexto de los bicentenarios de las independencias americanas funcionó, impulsando y renovando las preguntas en torno al lugar de los pueblos originarios en la historia. Es el caso de estas películas que se preguntan por el pasado, aunque, como se ha señalado, dicen más acerca del poder que el Estado desplegó en el territorio que sobre aquellos pueblos de Pampa y Patagonia. 
Sin embargo, cabe señalar que los filmes, permiten conocer a los sujetos sociales y sus estrategias actuales. Las entrevistas de Seguel en Tierra adentro y, algunas que se presentan un poco más elípticamente en El país del diablo, permiten focalizar en estos individuos y en esos colectivos, que exponen demandas acerca de la devolución de tierras. El tema aparece también enunciado en la dudas que presenta Marcos, en el viaje sobre los pasos de su tatarabuelo -en el que intenta diferenciarse y disculparse por los actos de su antepasado- pero sostiene respecto de la tierra apropiada:"Una cosa es la revisión de la historia y otra la reparación material".

Hacia el final, se destaca el testimonio de Raúl Eugenio Zaffaroni, entonces Juez de la Corte Suprema de Justicia -su nombre, subtitulando la imagen, marca una diferencia en el tratamiento como especialista o autoridad en la materia, ya que ninguno de los demás participantes habían sido presentados mediante esta estrategia-. Él afirma que la conquista del desierto puede considerarse una masacre estatal y, por tanto, es imprescriptible civilmente. Abona a la idea de un problema de reparación aún vigente. Allí cierra otro de los sentidos del texto en torno a la existencia de un actor social capaz de llevar adelante esa demanda de restitución territorial; la existencia de un grupo o colectivo indígena que se proyecte en esa arena política y judicial queda esbozada en ambos filmes. El tema cobra hoy nueva intensidad, debido a las muertes de Santiago Maldonado y Rafael Nahuel en el marco de la represión estatal a reclamos por la tierra en Patagonia.

\section{Notas}

1. Se denomina Wallmapu al territorio que los mapuches históricamente han habitado en Sudamérica: desde el río Limarí, por el norte; hasta el archipiélago de Chiloé, por el sur; y desde la latitud sur de Buenos Aires hasta la Patagonia.

2. Cynthia Tompkins: Afecto en Tierra adentro. [En línea] Imagofagia N. ${ }^{\circ}$ 16, p. 494. Disponible en: http://www.asaeca.org/imagofagia/index.php/imagofagia/issue/view/31/ showToc

3. La película describe el traslado de estos contingentes de vencidos, por tierra y por ferrocarril, con destino provisorio en la isla Martín García. Por su parte, el historiador Enrique Masés (2005), quien no adhiere a la idea del genocidio, arriesga que no menos de 5.000 personas provenientes del "desierto" fueron concentradas en distintas barracas de la Ciudad de Buenos Aires entre 1878 y 1885 en calidad de prisioneros. La viruela se convirtió, allí, en epidemia, debido a las paupérrimas condiciones de vida. Los que sobrevivieron a ella y al hambre esperaban ser distribuidos por la Comandancia General de Armas en los puntos ya mencionados o en las estancias e ingenios azucareros de Tucumán. Posteriormente, se encomendó esta tarea a La Sociedad de Beneficencia, la que, mediante avisos publicados en periódicos, anunciaba "la entrega de indios", a los que se exponía en un lugar público para que los interesados los eligieran para el servicio doméstico.

4. Raone, Juan Mario (1969): Fortines Del Desierto. Taller Gráf. Editorial Lito, 3 Tomos. 


\section{Bibliografía}

Amado, A. (2011). "Michael Moore y una narrativa del mal”, en Labaki y Mourao (comp.), El cine de lo real. Buenos Aires: Colihue Imagen.

Andermann, J. y Fernández Bravo, Á. (coord.) (2013). La escena y la pantalla. Cine contemporáneo y retorno de lo real. Buenos Aires: Colihue Imagen.

Barthes, R. (1992). La cámara lúcida. Notas sobre la fotografía. Barcelona: Paidos.

Bellour, R. (2009). Entre imágenes. Foto. Cine. Video. Buenos Aires: Colihue.

Carrasco, M. (ed.) (2000). Los derechos de los pueblos indígenas en Argentina Asociación de Comunidades Indígenas Lhaka Honhat y Grupo Internacional de Trabajo en Asuntos Indígenas. Serie Documentos en Español \# 30. Buenos Aires: Vinci Guerra.

Del Río, W. (2005). Memorias de expropiación. Sometimiento e incorporación indígena en la Patagonia. 1872-1943. Buenos Aires: UNQU-Prometeo.

Deotte, J. L. (1998). Catástrofe y olvido. Las ruinas, Europa, el museo. Santiago de Chile: Cuarto Propio.

Didi-Huberman, G. (2015). Remontajes del tiempo padecido. El ojo de la Historia 2. Buenos Aires: Universidad del Cine, Biblios.

Franca, A. (2013). "El cine documental y el retorno de lo que fue”, en Álvaro Fernández Bravo y Jens Andermann (Comp.) La escena y la pantalla cine contemporáneo y el retorno de lo real. Buenos Aires: Colihue Images.

Huyssen, A. (2003). En busca del futuro perdido. Cultura y memoria en tiempos de globalización. FCE.

Masés, E. (2005). Estado y cuestión indígena. El destino final de los indios sometidos en el sur del territorio (1878-1910). Buenos Aires: Prometeo libros-Entrepasados.

Penhos, M. (2005). "Frente y perfil. Una indagación acerca de la fotografía en las prácticas antropológicas y criminológicas en Argentina a fines del siglo XIXy principios del XX", en Arte y Antropología en la Argentina. Buenos Aires: Fundación Espigas.

Piedras, P. (2014). Reparaciones y enmascaramientos. Estrategias discursivas para elaborar el pasado traumático en el documental y la literatura autobiográficos. Revista de Estudios sobre Genocidio. Año 6, volumen 9, Buenos Aires, julio, pp. 77-92.

Rodríguez, A. (2015). Historia, pueblos originarios y frontera en el cine nacional. Bernal: Universidad Nacional de Quilmes.

Rodríguez, A. (2017). "Historia y archivo en Tierra Adentro. Entre la restitución y la repetición”; en Elizondo C. y Rodríguez A. (comp.), Tiempo archivado. Materialidad y espectralidad en el audiovisual. Bernal: Universidad Nacional de Quilmes.

Torre, C. "El desierto argentino y la bruma del progreso". Sobre El país del Diablo de Andrés Di Tella. Contracorriente, Vol. 7, No. 1, Fall 2009, 254-256 www.ncsu.edu/project/ acontracorriente (consultado el 2/12/2017).

Vezub, J. E. (2011). 1879-1979: Genocidio indígena, historiografía y dictadura. [En línea]. Archivos virtuales de la alteridad americana. Disponible en: http://ppct.caicyt.gov.ar/ index.php/corpus/issue/view/51/showToc (consultado el 2/03/2017).

Vanni, B. (2005). La zanja de la Patagonia. Los nuevos conquistadores: militares, científicos, sacerdotes, escritores. Buenos Aires: Fondo de Cultura Económica.

Wieviorka, A. (2005). 60 ansapres. Paris: Robert Lafont. 
Walter, J. C. (1970). La Conquista del desierto. Lucha de frontera con el indio. Buenos Aires: Eudeba.

Tomkins, C. (2017). “Afecto en Tierra adentro”. Imagofagia N. o 16, p. 494 http://www.asaeca. org/imagofagia/index.php/imagofagia/issue/view/31/showToc

Zylberman, L. (2017). "Cine Documental y genocidio. Hacia un abordaje integral”. Actas de las XVI Jornadas interescuelas / Deptos de Historia, Universidad de Mar del Plata, agosto 2017. https://interescuelasmardelplata.com/actas/

\begin{abstract}
In the representation of the past, whether as drama or as a document, the films turn to archive, they use a pictorial, documentary or material source, because they there is where they find an intrinsic power of legitimation, beyond the possible subsequent use of these sources. The paper proposes the analysis of two recent documentaries that address the problem of the so-called Conquest of the Desert: "El pais del Diablo" by Andrés Di Tella (2008) and "Tierra Adentro" by Ulises de la Orden (2011). Some hypotheses are raised about how the cinema of historical theme builds the credible, what place the archive has in that construction and what type of use is made of the documentary and iconographic sources, and, mainly, of the oral testimonies in said representations. An attempt is made to account for some text-context relationships, as well as to inquire about the notions about the history that both films are filming.
\end{abstract}

Key words: cinema - Argentine history - indigenous communities - documentaries - cultural analysis.

Resumo: Na representação do passado, sejam como drama ou documento, os filmes apelam ao arquivo, se valem de alguma fonte pictórica, documental ou de restos materiais, porque é o lugar onde se encontra um poder de legitimação intrínseco, além do uso que depois possa fazer-se dessas fontes. O trabalho propõe a análise de dois documentais recentes que abordam a problemática da chamada Conquista do Deserto: O pais do diabo de Andrés Di Tella (2008) e Terra Adentro de Ulises de la Orden (2011). Esboçam-se algumas hipóteses acerca de como se constrói o verosímil o cinema de tema histórico, que lugar tem o arquivo nessa construção e que tipo de uso se faz das fontes documentais, iconográficas, e, principalmente, das testemunhas orais nessas representações. Procura-se dar conta de algumas relações texto-contexto, além de indagar sobre as noções sobre a história que põem a rodar ambos os filmes.

Palavras chave: cinema - história argentina - povos originários - documentais - análise cultural. 